\title{
Analysis on the investment environment of Turkmenistan
}

\section{transportation industry}

\author{
Gao Yang \\ The Central Asian Economic Research Institute, China (Xinjiang) and Central Asia Regional \\ Economic Cooperation Research Center, Xinjiang University of Finance \&Economics, Urumqi \\ 830000, China; Xinjiang Vocational University, Urumqi 830013, China
}

highrise416@163.com

\begin{abstract}
Keywords: Turkmenistan; transportation industry;investment environment
Abstract: This paper mainly introduces Turkmenistan's development status and investment policy of the transportation industry, and analyzes the favorable factors and investment risk of Turkmenistan's environment, then based on the particularity of the transportation project proposes that when China enterprises invest in Turkmenistan should make full use of relevant preferential policies, adequate investigation and evaluation of the proposed investment projects and make the effort to avoid investment risk. On the basis of mutual benefit, it will enhance the level of economic development in two countries.
\end{abstract}

\section{Introduction}

Along with the development of the tide of regional economic integration and economic globalization, many countries are committed to regional economic cooperation, complementary advantages and enhance their economic development level. The Turkmenistan is an important transport node between regions and the geographical position is superior. Turkmenistan has great potential and transit transport which committed to optimizing the joint air ground transportation system. Turkmenistan has become an important international and regional seas, rivers, roads, railways, air transport hub. China enterprises "going out" in cooperation with Turkmenistan in the field of traffic which meet both sides the reality of demand to seek their own economic progress. It not only can strengthen and promote regional economic development, but also has a positive practical significance of economic globalization.

\section{Turkmenistan transportation industry development status and related investment policy}

The total length of the Turkmenistan railway mileage is 4000 kilometers, there is no electrified railway. Total length of road is about 14 thousand kilometers, which is about $2 / 3$ built in recent more than ten years ,and there is no highway. In water transport, The Port of Head is the largest port of the east coast of the Caspian Sea, and which is also the main export channel such as crude oil, refined oil, polypropylene and other goods.Caspian Sea Port is the gateway of Turkmenistan to other countries , and which is also the trade hub of Central Asia, Iran and other countries. In air transport, domestic and international shipping lines is more than 50 lines, which is accounted for $60 \%$ of international routes.

In 2015, transportation and communication services of Turkmenistan completed over the $14.2 \%$ of the plan, and the growth rate is $15.1 \%$. Land and water empty cargo volume has increased, passenger growth is $2.8 \%$, in which road passenger transport is $3.3 \%$, rail and air passenger transport is $0.2 \%$, water passenger transport is $37.6 \%$.

In the Turkmenistan foreign investment law, Turkmenistan implement license management system include inland shipping, road transport and other industries. But China and Turkmenistan as early as November 1992 signed 'People's Republic of China and Turku concerning the 
encouragement and reciprocal protection of investment agreement'. In September 2013, 'Joint Declaration on the establishment of strategic partnership between People's Republic of China and Turkmenistan' published, the article proposed that the two sides will fully expand infrastructure construction, telecommunications, chemical industry, textile industry, agriculture, health, technology and other areas of cooperation, establish and implement the mutually beneficial cooperation project, and strengthen cooperation in the field of infrastructure. More over, the two sides will promote and take measures to protect mutual investment, and provide support for the two companies doing business in each other's countries.

\section{Analysis on the investment environment of Turkmenistan transportation industry}

\section{(I) Positive factors}

Turkmenistan in attracting foreign investment is mainly in three aspects of competitive advantages: political stability, social undertakings have developed rapidly; rich in oil and gas reserves, good prospects for economic growth; the location is in the center of the Eurasian continent. From 2008 to 2015, the Turkmenistan economy has maintained sustained and rapid growth. In 2014, the gross domestic product is grew by $10.3 \%$.

Table 1 Macroeconomic statistics of Turkmenistan in 2008-2015

USD bln.

\begin{tabular}{|c|c|c|c|c|c|c|c|c|}
\hline Year & 2008 & 2009 & 2010 & 2011 & 2012 & 2013 & 2014 & 2015 \\
\hline GDP & 142.48 & 151.17 & 165.08 & 189.34 & 210.37 & 231.82 & 255.70 & 272.32 \\
\hline $\begin{array}{c}\text { GDP } \\
\text { Increases\% }\end{array}$ & $14.7 \%$ & 6.1 & 9.2 & 14.7 & 11.1 & 10.2 & 10.3 & 6.5 \\
\hline
\end{tabular}

Source:http://www.mofcom.gov.cn/article/i/dxfw/ae/201504/20150400930514.shtml

Turkmenistan's transportation system is in the steady development and the international transport corridor is in the continuous construction. During the last 5 years, between the contribution of transportation industry to Turkmenistan GDP is $4 \%-6 \%$, the industry invested more than $\$ 7$ billion, in which the production of transport and communications investment accounted for $12 \%-19 \%$.On May the 12th in 2014, China and Turkmenistan signed the first cooperation documents in the field of transportation, which laid a solid foundation for the future to two countries deepen bilateral cooperation in the field of transportation, road connectivity and promote cross-border transport cooperation.

Table 2 Turkmenistan's main indicators of freight transport growth rate compared with the situation in 2014

\begin{tabular}{|l|l|l|}
\hline Transportation Methods & Freight & Turn - over \\
\hline Total (excluding pipeline transport) & $4.7 \%$ & $0.3 \%$ \\
\hline Including: highway & $5.4 \%$ & $6.2 \%$ \\
\hline air transport & $2.7 \%$ & $0.2 \%$ \\
\hline Water transportation & $5.1 \%$ & $0.1 \%$ \\
\hline
\end{tabular}

Source:http://www.mofcom.gov.cn/article/i/dxfw/ae/201602/20160201262132.shtml 
Table 3 Turkmenistan's main indicators of passenger transportation growth rate compared with the situation in 2014

\begin{tabular}{|l|l|l|}
\hline Transportation methods & Passenger Capacity & Guest Turnover \\
\hline Total & $3.5 \%$ & $2.8 \%$ \\
\hline Including: highway & $3.5 \%$ & $3.3 \%$ \\
\hline air transport & $0.1 \%$ & $0.2 \%$ \\
\hline Water transportation & $0.1 \%$ & $0.2 \%$ \\
\hline Including: highway & $14.3 \%$ & $37.6 \%$ \\
\hline
\end{tabular}

Source:http://www.mofcom.gov.cn/article/i/dxfw/ae/201602/20160201262132.shtml

From Table 2 and Table 3,we can see that both freight transport growth and passenger transportation growth of Turkmenistan grew rapidly.

\section{(II) Investment risk}

Turkmenistan's political and economic system is highly concentrated, the market mechanism is underdeveloped, government agencies often carry out administrative intervention and examination of foreign enterprises or foreign cooperation projects with foreign investment. The relevant laws and regulations are not perfect, such as the arbitrariness of law enforcement. Finance and foreign exchange market is not open to the outside of the world, influenced by national policies.

\section{Suggestions on the investment of Chinese enterprises to Turkmenistan transportation industry}

First of all, the transportation industry in Turkmenistan is to encourage foreign investors to enter the field, which has the related regulations on preferential policies on investment. So in the specific investment, we must fully and detailed understanding of the Turkmenistan in the field of transportation, using a variety of preferential policies, so that we can use it in the investment and operation of the process in the future.

Secondly, investment in transportation projects have a long construction period and investment return period is long. So before the investment, enterprises must investigate fully on the proposed investment project, analysis and evaluation including credit investigation on the project or customer and related parties and assess, avoid local political risks and business risk, the implementation of the project itself. The feasibility analysis can make full use of the local government, intermediary organizations and China Embassy Commercial Counsellor's Office, through which receive real and effective information related investment projects as far as possible.

Thirdly, in the process of investment, China enterprises should make risk aversion and management work which can protect their own interests effectively. Then enterprises should hire powerful consultant to deal with the relationship between the various levels of government and the legal aspects of the matter. In addition, the Ministry of commerce also suggested China enterprises to use China Export and Credit Insurance Corp, which can provide in the field of foreign investment cooperation in the process of the company, including political risk, commercial risk, credit risk protection. It is very necessary and important for the Chinese enterprises in the prevention of investment risk. 
Last, Chinese enterprises should establish a good image. From the development of the economy, expanding employment, enthusiastic public welfare and other aspects of positive return to the local community, avoiding unnecessary misunderstanding and easing the exclusion and doubt of investment of Chinese enterprises.

\section{Acknowledgements}

This work was financially supported by the Fund of the Key Research Center of Humanities and Social Sciences in the general Colleges and Universities of Xinjiang Uygur Autonomous Region (code:050115C02) and the Fund of the Xinjiang University of Finance and Economics Doctor graduate Student research innovation project (code:XJUFE2016K028).

\section{REFERENCES}

[1] Information on http://www.mofcom.gov.cn/article/i/jyjl/e/201607/20160701360667.shtml

[2] Information on http://tm.mofcom.gov.cn/article/jmxw/201407/20140700659468.shtml

[3] Information on http://www.zgjtb.com/content/2014-05/13/content_83296.htm

[4] Information on http://news.xinhuanet.com/world/2013-09/04/c_117214884.htm

[5] Information on http://www.mofcom.gov.cn/article/i/dxfw/ae/201504/20150400930514.shtml 